\title{
Mereduksi Superioritas dan Mengamalkan Sila "Kemanusian yang Adil dan Beradab" dalam Perspektif Kristiani
}

\author{
Yonatan Alex Arifianto \\ Sekolah Tinggi Teologi Sangkakala, Salatiga \\ arifianto.alex@gmail.com
}

\begin{abstract}
The diversity of the Indonesian population on the one hand is the strength of the Indonesian nation, but it can also be a trigger for the disintegration of fellow nation's children. The number of SARA conflicts that occurred after the reformation gave rise to superiority in various levels of society to the superiority of religion. Through this paper, the writer describes about reducing superiority and practicing just and civilized human precepts. Using descriptive qualitative research methods, it can be concluded that in order to reduce superiority and also in practicing the precepts and norms contained therein, what needs to be done as follows: First, every child of the nation must be able to eliminate the sense of superiority from all sides towards respect for others by reducing the wrong paradigm of the nature of humanity. Second, continue to strengthen and continue to practice unity and integrity as the basis of the nation and state. Third, believers can see the human side from a Christian perspective which can be a guide in actualizing Christian faith in upholding human values.
\end{abstract}

Keywords: fair and civilized; humanity; justice; Pancasila

\begin{abstract}
Abstrak: Keberagaman penduduk Indonesia di satu sisi merupakan kekuatan bangsa Indonesia, namun juga dapat menjadi pemicu disintegrasi sesama anak bangsa. Banyaknya konflik SARA yang terjadi setelah reformasi, menimbulkan superioritas diberbagai lapisan masyarakat sampai kepada superioritas agama. Melalui tulisan ini penulis mendeskripsikan tentang mereduksi superioritas sebagai pengamalan sila "Kemanusian yang adil dan beradab". Dengan menggunakan metode penelitian kualitatif deskritif, dapat disimpulkan bahwa untuk mereduksi superioritas dalam mengamalkan sila dan norma yang terkandung di dalamnya maka yang perlu dilakukan sebagai berikut: Pertama, setiap anak bangsa harus dapat menghilangkan rasa superior atas sikap menghargai sesama dengan mereduksi paradigma hakikat kemanusiaan yang salah. Kedua, tetap memperkokoh dan terus mengamalkan persatuan dan kesatuan sebagai dasar hidup berbangsa dan bernegara. Ketiga, orang percaya dapat melihat sisi kemanusiaan dalam perspektif Kristiani yang dapat menjadi tuntunan untuk mengaktualisasi iman Kristen dalam menjunjung tinggi nilai kemanusiaan.
\end{abstract}

Kata kunci: adil dan beradab; keadilan; kemanusiaan; Pancasila

\section{PENDAHULUAN}

Dalam perkembangannya di era digital, serta dalam bingkai era reformasi, aktualisasi sila "kemanusiaan yang adil dan beradab" belumlah sepenuhnya dilakukan sesuai amanah Undang-Undang. Dewasa ini nilai humanisme semakin sulit dirasakan oleh sebagian masyarakat Indonesia. Tolok ukur ini bisa kita lihat pada tayangan-tayangan di media elektronik (TV, internet) yang setiap hari menyuguhkan berita yang sangat bertentangan dengan nilainilai kemanusiaan (human values). Berita pembunuhan, penganiayaan, pelecehan hampir 
tiap hari menjadi konsumsi masyarakat saat ini, dan merupakan suatu peristiwa yang tidak lagi aneh dalam mindset kita. Terlebih dewasa ini fenomena merajalelanya kekerasan dan pelanggaran hak-hak asasi manusia yang semakin luas dan tidak mengindahkan etika moral dan kemanusiaan semakin bermunculan di Indonesia. Hal ini bertolak belakang dengan Pancasila khususnya sila kedua yang menjadi dasar bahwa Indonesia sangat menjunjung tinggi nilai kemanusiaan. ${ }^{1}$

Masyarakat Indonesia sekarang ini menjadi sangat mudah emosional, dan menjadi warga negara yang disebut tidak sopan dalam berkomunikasi. ${ }^{2}$ Namun hal itu dibenarkan sebagai tindakan yang wajar walaupun terkadang bertentangan dengan hukum yang berlaku, kenyataan ini sangat tidak mencerminkan sila kemanusiaan yang adil beradab. Tidak bisa dipungkiri fenomena ini merupakan pengaruh dari terjadinya globalisasi di dunia. Budaya asing yang masuk oleh sebagian masyarakat Indonesia diterima tanpa difilter dampak positif dan negatifnya. ${ }^{3}$ Sedangkan, sejatinya, manusia membutuhkan keadilan dalam perlindungan hak asasi mereka sebagai makhluk sosial yang wajib dihormati dan dihargai. ${ }^{4}$ Adanya kasus yang berkaitan dengan kemanusiaan seperti terjadinya kasus human trafficking dan adanya bentuk ketidakadilan dalam bidang ekonomi parsialitas dalam marginalisasi status sosial ekonomi bagi masyarakat. ${ }^{5}$

Nilai-nilai Pancasila menjadi pedoman atau norma bagi masyarakat majemuk yang menghargai perbedaan suku, budaya, ras dan agama. Terlebih nilai Pancasila dapat menjaga persatuan dan kesatuan, menjaga kerukunan, serta menghindari sikap etnosentrisme. ${ }^{6}$ Manusia cenderung memiliki sikap negatif yang menghambat kerukunan umat beragama, yakni fanatisme sempit, egoisme, truth claim dan keengganan memahami dan bersikap terbuka terhadap agama lain. ${ }^{7}$ Perlakuan ketidakadilan itu diterima oleh masyarakat. hal itu menginspirasi adanya penghormatan terhadap manusia sebagai makluk yang beradab, sebab ketidakadilan terhadap masyarakat yang diperlakukan tidak manusawi menuntut adanya penghargaan terhadap nilai-nilai kemanusiaan dan keadilan. ${ }^{8}$

${ }^{1}$ Umiarti Karimah, "Kemanusiaan Yang Adil Dan Beradab Perspektif Al-Quran (Studi Komparatif Tafsir Al-Misbah Dan Al-Huda)," 2018, http://repository.iiq.ac.id/handle/123456789/753.

${ }^{2}$ Aditya Jaya Iswara, "6 Bukti Netizen Indonesia Tidak Sopan Se-Asia Tenggara, Akun Luar Pun Diserang," Kompas.com, 2021, https://www.kompas.com/global/read/2021/04/14/100430270/6-buktinetizen-indonesia-tidak-sopan-se-asia-tenggara-akun-luar-pun?page=all.

${ }^{3}$ Rini Aristin, “Aktualisasi Sila Kemanusiaan Yang Adil Dan Beradab Di Era Reformasi,” Aspirasi : Jurnal Ilmiah Administrasi Negara 1, no. 1 (2016): 27-36,

http://ejournal.unira.ac.id/index.php/jurnal_aspirasi/article/view/39/24\%0Ahttp://ejournal.unira.ac.id/index.p hp/jurnal_aspirasi/article/view/39.

${ }^{4}$ Ferry Irawan Febriansyah, "Keadilan Berdasarkan Pancasila Sebagai Dasar Filosofis Dan Ideologis Bangsa," DiH: Jurnal Ilmu Hukum 13, no. 25 (2017): 1-27, https://doi.org/10.30996/dih.v13i25.1545.

${ }^{5}$ Desti Samarenna, "Penghayatan Dan Pengalaman Pancasila Dalam Refleksi Matius 22: 37-40," JURNAL TERUNA BHAKTI 3, no. 1 (2020): 36-47.

${ }^{6}$ Bagus Pradhana Krisnamukti et al., "Nilainilai Pancasila Menjadi Pedoman Atau Normal Bagi Masyarakat Dalam Kehidupan Sosial Yang Terdapat Kemajemukan Suku, Budaya, Ras Dan Agama Untuk Tetap Saling Menjaga Persatuan Dan Kesatuan, Menjaga Kerukunan, Serta Menghindari Sikap Etnosentrisme.," Jurnal Rontal Keilmuan Pancasila Dan Kewarganegaraan 6, no. 1 (2020): 66-72.

${ }^{7}$ Umi Sumbulah, "Pluralisme Dan Kerukunan Umat Beragama Perspektif Elite Agama Di Kota Malang," Analisa Journal of Social Science and Religion 22, no. 1 (2015): 1-13.

${ }^{8}$ Ambiro Puji Asmaroini, "Menjaga Eksistensi Pancasila Dan Penerapannya Bagi Masyarakat Di Era Globalisasi,” JPK: Jurnal Pancasila Dan Kewarganegaraan 1, no. 2 (2017): 50-64. 
Namun keadilan manusia untuk masyarakat majemuk seperti Indonesia belum juga dapat disepakati. Persoalannya adalah bentuk keadilan tidak sejalan dengan pemahaman dan penilaian tentang keadilan. Keadilan saat ini bagi manusia merupakan suatu hal yang sangat sulit untuk diwujudkan. ${ }^{9}$ Sebagai bangsa yang majemuk, Indonesia mempunyai banyak suku bangsa, ras dan agama. Hal ini yang menyebabkan sulitnya mewujudkan keadilan yang diinginkan oleh bangsa yang majemuk seperti yang terjadi di Indonesia, karena definisi dari adil banyak ditafsirkan berbeda antara penafsiran oleh suku bangsa yang satu dengan suku bangsa yang lain. ${ }^{10}$

Berkaitan dengan topik mempertahankan eksistensi Pancasila terhadap sila "kemanusiaan yang adil dan beradab", pernah diteliti oleh Ellya Rosana yang memandang eksistensi Pancasila sebagai kontrak sosial umat beragama. ${ }^{11}$ Kesimpulan dari penelitian tersebut adalah, bahwa memantapkan keadilan dan pemenuhan moralitas tertinggi dengan mengedepankan kepentingan umum. Begitu juga dengan Gunawan Wibisono: melakukan penelitian serupa dalam artikel berjudul Membendung Paham Radikalisme Agama dan Ekstrim Kiri dalam Mempertahankan Eksistensi Pancasila, ${ }^{12}$ dengan kesimpulan Pancasila dalam kehidupan berbangsa dan bernegara merupakan cara yang strategis dalam membentengi bangsa yang utuh bersatu padu dan terkemuka serta memiliki daya saing yang kuat dalam menahan berbagai pengaruh paham yang tidak sesuai dengan kepribadian bangsa Indonesia. Adanya kedua penelitian tersebut masih ada hal-hal yang urgent tentang bagaimana sikap manusia dalam bernegara harus dapat menghargai sesama dan terlebih menghilangkan rasa superioritas dalam segala sisi kehidupan bermasyarakat. Sehingga membangun paradigma yang dapat menjadi acuan untuk menjunjung tinggi nilai kemanusiaan. Oleh sebab itu artikel ini akan meneliti dan membahas tentang topik tersebut.

\section{METODE}

Metode Jenis penelitian artikel ini adalah penelitian pustaka dengan pendekatan kualitatif deskriptif, dengan menggali literatur yang berkaitan dengan konsep mempertahankan eksistensi Pancasila. Selain itu penulis juga menggunakan teks-teks paralel Alkitab yang mendukung konsep kemanusiaan yang adil dan beradab untuk mendapatkan informasi deskriptif tentang manusia seutuhnya sebagai kajian yang dapat diteladani bagi orang kristen masa kini untuk diaplikasikan. Penulis juga mendeskripsikan manusia yang adil dan beradab sebagai kajian analisis berkaitan dengan kondisi masyarakat heterogen Indonesia berdasarkan firman Tuhan untuk melaksanakan hidup dalam hak-hak dan dalam damai sejahtera dibumi Indonesia tercinta di tengah kemajemukan masyarakat sosial.

\section{PEMBAHASAN}

Bangsa Indonesia mengenal istilah Pancasila jauh sebelum Indonesia mengalami kemerdekaan. Pancasila merupakan Landasan ideologi bangsa Indonesia. Secara harfiah Pancasila

\footnotetext{
${ }^{9}$ Febriansyah, "Keadilan Berdasarkan Pancasila Sebagai Dasar Filosofis Dan Ideologis Bangsa."

${ }^{10}$ Febriansyah.

${ }^{11}$ Ellya Rosana, “Eksistensi Pancasila Sebagai Kontrak Sosial Umat Beragama,” Jurnal Tapis: Jurnal Teropong Aspirasi Politik Islam 13, no. 2 (2017): 1-17.

${ }^{12}$ Gunawan Wibisono, "Membendung Paham Radikalisme Agama Dan Ekstrim Kiri Dalam Mempertahankan Eksistensi Pancasila," Communitarian 1, no. 1 (2018).
} 
terdiri dari dua kata yaitu "Panca" yang berarti lima dan "sila" yang berarti aturan yang melatar belakangi perilaku seseorang atau bangsa, kelakuan atau perbuatan sesuai dengan adab yang dijadikan sebagai dasar. Karena itu, Pancasila berarti rangkaian lima aturan tentang dasar-dasar atau prinsip-prinsip petunjuk perilaku dan perbuatan masyarakat bangsa indonesia. ${ }^{13}$ Pancasila sebagai dasar dan ideologi negara harus dijadikan pedoman dan pandangan hidup bagi seluruh warga negara dalam seluruh kehidupan bermasyarakat, berbangsa, dan bernegara. Sebagai suatu dasar filsafat negara, maka sila-sila Pancasila merupakan suatu sistem nilai dan norma. Oleh karena itu, sila-sila Pancasila pada hakikatnya merupakan satu kesatuan. Meskipun dalam setiap sila terkandung nilai-nilai yang memiliki perbedaan antara satu dengan lainnya, namun kesemuanya itu merupakan satu kesatuan yang sistematis. ${ }^{14}$ Hal itu dijadikan prinsip-prinsip sebagai pedoman hidup bangsa Indonesia sejak bangsa Indonesia ada. ${ }^{15}$

Pancasila sebagai dasar dalam pembentukan hukum atau menjadi tonggak utama dalam membentuk peraturan perundang-undangan yang sesuai dengan jiwa bangsa Indonesia yang memanusiakan manusia yang adil dan beradab serta berkeadilan sosial bagi seluruh rakyat Indonesia. ${ }^{16} \mathrm{Hal}$ itu didasari oleh penegakan hak asasi manusia yang merupakan perwujudan dari sila kemanusiaan yang beradab dapat memberikan kesamaan perlakuan dan harkat martabat kepada semua masyarakat Indonesia tanpa terkecuali, tanpa melihat apa jabatan, apa warna kulit, apa agamanya, apa sukunya dan masih banyak lagi. ${ }^{17}$ Penegakan dan perlindungan tentang hak asasi manusia di Indonesia sangatlah penting bagi rakyatnya, karena hak asasi manusia berkaitan dengan harkat dan martabat manusia sebagai manusia seutuhnya. ${ }^{18}$ Nilai kemanusiaan mengharapkan manusia untuk mengakui dan memperlakukan manusia sesuai dengan harkat dan martabatnya, mengakui persamaan derajat, persamaan hak dan kewajiban asasi manusia, mencintai sesama manusia, menciptakan sikap tenggang rasa dan tepa selira, serta menjungjung tinggi nilai kemanusiaan dan berani membela kebenaran dan keadilan. ${ }^{19}$ Dan menghilangkan sikap merasa berkuasa dalam bermasyarakat.

Sejatinya, nilai karakteristik keadilan berdasarkan Pancasila merupakan nilai-nilai keadilan yang berupa prinsip-prinsip keadilan, memenuhi beberapa asas-asas atau prinsipprinsip yang meliputi prinsip keadilan berdasar atas Ketuhanan Yang Maha Esa. Prinsip keadilan Pancasila mengedepankan hak asasi manusia serta memanusiakan manusia sebagai mahkluk sosial yang wajib dilindungi keadilannya. ${ }^{20}$ Oleh karena itu Pancasila yang sudah

\footnotetext{
${ }^{13}$ Sulistyani Eka Lestari, “Kajian Islam Terhadap Sila Kedua Dalam Pancasila Sebagai Penjaga Multikulturalisme," Pendidikan Multikultural 3, no. 2 (2019): 190-206, https://doi.org/10.33474/multikultural.v3i2.4759.

${ }^{14}$ Aristin, "Aktualisasi Sila Kemanusiaan Yang Adil Dan Beradab Di Era Reformasi."

${ }^{15}$ Krisnamukti et al., "Nilainilai Pancasila Menjadi Pedoman Atau Normal Bagi Masyarakat Dalam Kehidupan Sosial Yang Terdapat Kemajemukan Suku, Budaya, Ras Dan Agama Untuk Tetap Saling Menjaga Persatuan Dan Kesatuan, Menjaga Kerukunan, Serta Menghindari Sikap Etnosentrisme.”

${ }^{16}$ Febriansyah, "Keadilan Berdasarkan Pancasila Sebagai Dasar Filosofis Dan Ideologis Bangsa."

${ }^{17}$ Arifin and Lestari, "Penegakan Dan Perlindungan Hak Asasi Manusia Di Indonesia Dalam Konteks Implementasi Sila Kemanusiaan Yang Adil Dan Beradab."

18 Arifin and Lestari.

${ }^{19}$ Firman Freaddy Busroh, "Upaya Pencegahan Korupsi Melalui Reaktualisasi Nilai-Nilai Pancasila," Jurnal Ilmiah Lex Publica IV, no. 1 (2017): 631-44.

${ }^{20}$ Febriansyah, "Keadilan Berdasarkan Pancasila Sebagai Dasar Filosofis Dan Ideologis Bangsa."
} 
final dijadikan dasar dan Ideologi Negara Republik Indonesia yang ada sejak negara Indonesia belum berdiri, dan dijadikan pilar dalam berbangsa serta membangun peradaban yang maju. Dasar itu juga mengandung nilai-nilai bermasyarakat, berbangsa, dan bernegara. Kedudukan Pancasila sebagai dasar dan Ideologi Negara yaitu sebagai fondamen, filsafat, pikiran yang mendalam, pandangan hidup, dan pemersatu bangsa. ${ }^{21}$ Pancasila merupakan kontrak sosial bagi seluruh rakyat Indonesia yang nota bene adalah umat yang beragama yang harus dijalankan secara konsisten dan bertanggung jawab. ${ }^{22}$ Untuk itu sikap apa yang harus dilakukan oleh orang percaya dalam mempertahankan eksistensi Pancasila terhadap sila kemanusiaan yang adil dan beradab adalah:

\section{Mereduksi Paradigma Hakikat Kemanusiaan yang Salah}

Sila kemanusiaan yang adil dan beradab sebagai dasar fundamental dalam kehidupan kenegaraan, kebangsaan, dan kemasyarakatan. Kemanusiaan yang adil dan beradab juga mengandung suatu nilai kesadaran sikap moral dan tingkah laku manusia yang didasarkan pada potensi budi dan nurani manusia dalam hubungan dengan norma-norma dan kebudayaan pada umumnya baik terhadap diri sendiri, terhadap sesama manusia maupun terhadap lingkungannya. ${ }^{23}$ Kemanusiaan yang adil dan beradab memiliki makna substansial pengakuan terhadap harkat dan martabat manusia yang luhur, tanpa harus dibeda-bedakan antara satu sama lainnya karena perbedaan keyakinan politik, status sosial dan ekonomi, asalusul, keturunan, ras, warna kulit, bahasa, agama, budaya, adat istiadat, suku, dan perbedaan lainnya. Sehingga perwujudan dari kepribadian seseorang akan tampak dalam keseluruhan pribadi manusia dalam hubungan interaksinya dengan manusia lainnya di lingkungan hidupnya. ${ }^{24}$ Kedudukan yang sederajat dalam bersosial dan dalam bermasyarakat harus dilaksanakan sebagai bagian dari menjunjung tinggi kemanusiaan, maka manusia mengharuskan dirinya untuk bisa saling menghargai sesamanya. ${ }^{25}$ Nilai kemanusiaan yang adil dan beradab juga mengandung arti, bahwa Negara harus menjunjung tinggi harkat dan martabat manusia sebagai makhluk yang beradab. Oleh karena itu dalam kehidupan kenegaraan terutama dalam peraturan perundang-undangan Negara harus mewujudkan tercapainya tujuan martabat dan harkat manusia, terutama hak-hak dasar kodrat manusia (hak asasi), Kesadaran sikap moral dan tingkah laku manusia yang didasarkan pada potensi budi pekerti manusia. Yang juga memiliki hubungan dengan norma-norma dan kebudayaan baik terhadap diri sendiri, terhadap sesama manusia maupun terhadap lingkungannya, adalah perwujudan dari pengamalan nilai-nilai kemanusiaan sebagai makhluk yang berbudaya bermoral dan beragama. $^{26}$

\footnotetext{
${ }^{21}$ Felisia Mega Sri Ayu and Anita Trisiana, "Penguatan Pancasila Dalam Perbuatan (Alternatif Tindakan Kuratif Di Era Globalisasi)," Jurnal Global Citizen: Jurnal Ilmiah Kajian Pendidikan Kewarganegaraan 4, no. 2 (2018): 14-19.

${ }^{22}$ Rosana, "Eksistensi Pancasila Sebagai Kontrak Sosial Umat Beragama."

${ }^{23}$ Aristin, "Aktualisasi Sila Kemanusiaan Yang Adil Dan Beradab Di Era Reformasi."

${ }^{24}$ Dukha Yunitasari, "Mengupas Hakikat Manusia Sebagai Makhluk Pendidikan Dan Implikasinya," Pelita Bangsa Pelestari Pancasila 13, no. 1 (2018): 77-93.

${ }^{25}$ Agus Sutono and Supriyono Purwosaputro, “Aksiologi Pancasila," Jurnal Ilmiah Civis 8, no. 2 (2019): 67-86.

${ }^{26}$ Dwi Yanto, "Pengamalan Nilai-Nilai Pancasila Sebagai Pandangan Hidup Dalam Kehidupan Sehari-Hari,” Ittihad 14, no. 25 (2016): 35-45, https://doi.org/10.18592/ittihad.v14i25.860.
} 
Namun, realitanya konsep kemanusiaan yang adil dan beradap belum seutuhnya terealisasi dengan baik. Ketidakberdayaan itu dapat dibaca sebagai kondisi buruk yang dapat menggiring seseorang atau sekelompok orang terjerumus dalam perbuatan kriminalitas dan radikalisme yang mengarah pada prilaku intoleransi maupun terorisme. ${ }^{27}$ Terlebih adanya bentuk perbuatan yang ditunjukkan dengan melecehkan sila kedua dari Pancasila ini adalah kekerasan atau radikalisme baik secara individual maupun kelompok. Begitu juga adanya para pemimpin bangsa yang tidak melaksanakan atau menegakkan keadilan dan hanya mementingkan diri sendiri dengan memperkaya melalui korupsi dan kebijakan yang tidak mementingkan rakyat. ${ }^{28}$ Untuk itu perlu diadakan penegakkan bagi seluruh lapisan masyarakat yang tindakannya melenceng dari dasar negara.

Manusia yang merupakan cerminan atau perwujudan dari sila pancasila yang kedua yaitu kemanusiaan yang adil dan beradab wajib memberikan penghargaan terhadap hak asasi manusia yang dilindungi oleh Undang-Undang. Maka hal itu harus terus diupayakan sebagai sikap mereduksi paradigma yang salah tentang hakikat manusia. ${ }^{29} \mathrm{Hal}$ itu dapat dilakukan dengan memberikan kajian yang benar tentang hakikat manusia dalam seluruh pendidikan baik secara formal maupun non formal dengan menjauhkan dari sikap eksklusif dan menganggap diri dan kelompok serta ajaran agama paling benar. Pemahaman hak asasi manusia bagi bangsa Indonesia sangatlah penting di tanamkan bagi semua masyarakat yang ada di Indonesia. Hak asasi manusia sebagai anugerah dari Tuhan Yang Maha Esa melekat pada diri manusia, bersifat universal, kodrati, dan abadi, yang berkaitan dengan harkat dan martabat manusia. Setiap manusia diakui dan dihormati dengan hak asasi manusia tanpa membedakan warna kulit, jenis kelamin, kebangsaan, agama, usia, pandangan politik, status sosial, dan bahasa daerah. ${ }^{30}$

\section{Dasar berbangsa dan bernegara}

Bangsa Republik Indonesia memiliki Ideologi yang luhur yaitu Pancasila sebagai ideologi final negara yang mengikat seluruh bangsa yang majemuk. Oleh karena itu, Pancasila mempunyai posisi yang strategis dan fundamental yaitu sebagai jati diri, kepribadian, moralitas, dan haluan keselamatan bangsa. ${ }^{31}$ Di dalam kehidupan bermasyarakat prinsip Pancasila tidak membeda-bedakan manusia berdasarkan agama, ras, warna kulit atau budaya. Pandangan Pancasila mengakui adanya pluralisme yang memungkinkan berkembangnya suatu nasionalisme yang inklusif. ${ }^{32}$ Pancasila juga sebagai dasar fundamental bagi seluruh rakyat Indonesia merupakan fondasi negara, serta sumber penegakan hukum nasional di Indonesia dan juga menjadi ideologi nasional. ${ }^{33}$ Pancasila juga memiliki pengertian nilai-nilai yang terkandung di dalamnya menjadi landasan bagi masyarakat Indonesia dalam menjalankan praktik-praktik kehidupannya sehari-hari dalam bermasyarakat. ${ }^{34}$ Atau dapat disebut sebagai pedoman tingkah laku atau pedoman hidup yang berakar dari karya, rasa, gagasan, cipta dan

\footnotetext{
${ }^{27}$ Lestari, “Kajian Islam Terhadap Sila Kedua Dalam Pancasila Sebagai Penjaga Multikulturalisme.”

${ }^{28}$ Lestari.

${ }^{29}$ Arifin and Lestari, "Penegakan Dan Perlindungan Hak Asasi Manusia Di Indonesia Dalam Konteks Implementasi Sila Kemanusiaan Yang Adil Dan Beradab."

${ }^{30}$ Arifin and Lestari.

${ }^{31}$ Supriardoyo Simanjuntak and Kornelius Benuf, "Relevansi Nilai Ketuhanan Dan Nilai Kemanusiaan Dalam Pemberantasan Tindak Pidana Korupsi," DIVERSI : Jurnal Hukum 6, no. 1 (2020): 2246, https://doi.org/10.32503/diversi.v6i1.890.

${ }^{32}$ Asmaroini, "Menjaga Eksistensi Pancasila Dan Penerapannya Bagi Masyarakat Di Era Globalisasi."

33 A.M.W. Pranarka, Sejarah Pemikiran Tentang Pancasila (Jakarta: Yayasan Proklamasi, 1985), 4.

${ }^{34}$ Simanjuntak and Benuf, "Relevansi Nilai Ketuhanan Dan Nilai Kemanusiaan Dalam Pemberantasan Tindak Pidana Korupsi."
} 
pemikiran masyarakat Indonesia. ${ }^{35}$ Sehingga konsep dan arti kemanusiaan yang sesungguhnya dapat terangkum jelas dan bermakna bahwa nilai kemanusiaan merupakan perwujudan dari nilai kemanusiaan sebagai makhluk yang berhati nurani, berbudaya, bermoral dan beragama. ${ }^{36}$ Dan hal ini menjadi point penting untuk membangun keutuhan bangsa dan negara serta menguatkan kebersamaan dalam melaksanakan komitment dasar bernegara.

Mengingat bahwa begitu strategisnya kedudukan Pancasila sebagai dasar pemersatu bangsa Indonesia, maka pancasila harus tetap dipertahankan dan dilestarikan dengan melalui revitalisasi dan aktualisasi dalam kehidupan bermasyarakat, berbangsa dan bernegara. ${ }^{37}$ Untuk itu setiap anak bangsa perlu pemahaman terhadap sila kemanusiaan yang adil dan beradab ini yang sejatinya mengandung nilai-nilai kemanusiaan yaitu adanya sebuah pengakuan terhadap harkat dan martabat manusia dengan segala hak dan kewajibannya, selain itu adanya perlakuan yang adil terhadap sesama manusia, diri sendiri, alam sekitar, dan terhadap Tuhan. ${ }^{38}$ Sila ini juga menegaskan bahwa manusia sebagai makhluk beradab atau berbudaya yang memiliki daya cipta, rasa, karsa dan keyakinan yang kuat untuk menghargai sesama. ${ }^{39}$ Terlebih juga dalam sila yang kedua ini ada esensi kemanusiaan yang adil dan beradab yang menunjukkan ciri khas bangsa indonesia yang sebenarnya bahwa bangsa Indonesia selalu menghormati hak, harkat dan martabat manusia dalam wujud hak asasi manusia. ${ }^{40}$

Negara Indonesia adalah negara hukum yang selalu menjunjung tinggi keadilan dan juga kepastian hukum bagi seluruh masyarakatnya. Hukum diciptakan untuk mengendalikan dan mentertibkan masyarakat serta agar masing-masing subjek hukum dapat menjalankan kewajibannya dengan baik dan mendapatkan haknya. ${ }^{41}$ Sebab mereka sama-sama memiliki martabat yang tinggi, karena itu harus diperlakukan sesuai dengan nilai-nilai kemanusiaan, sesuai dengan fitrahnya sebagai makhluk Tuhan ${ }^{42}$

\section{Konsep Kemanusian yang Adil dan Beradab dalam Pandangan Alkitab}

Manusia memiliki kepribadian yang berbeda dimana hal itu diciptakan Tuhan untuk saling membangun dan bersosial serta menghargai sesamanya. Namun bukan itu saja, manusia yang sejatinya memiliki nilai plus dari makluk yang lainnya adalah manusia memiliki hubungan khusus dengan Allah $^{43}$, dan juga memiliki sifat saling ketergantungan dengan

${ }^{35}$ Kornelius Benuf, "Politik Hukum Legislator Dan Ideologi Pancasila," Gema Keadilan 5, no. 1 (2018): 85-92.

${ }^{36}$ Simanjuntak and Benuf, "Relevansi Nilai Ketuhanan Dan Nilai Kemanusiaan Dalam Pemberantasan Tindak Pidana Korupsi."

${ }^{37}$ Natal Kristiono, "Penguatan Ideologi Pancasila Di Kalangan Mahasiswa Universitas Negeri Semarang," Harmony 2, no. 2 (2017): 193-204.

${ }^{38}$ Rosana, "Eksistensi Pancasila Sebagai Kontrak Sosial Umat Beragama." 89.

${ }^{39}$ Soejadi, Pancasila Sebagai Sumber Tertib Hukum Indonesia (Yogyakarta: Lukman Offset, 1999),

${ }^{40}$ Arifin and Lestari, "Penegakan Dan Perlindungan Hak Asasi Manusia Di Indonesia Dalam Konteks Implementasi Sila Kemanusiaan Yang Adil Dan Beradab."

${ }^{41}$ Arifin and Lestari.

${ }^{42}$ Darmodiharjo, Darji.Santiaji Pancasila,Surabaya: Usaha Nasional. 1991,40

${ }^{43}$ Hannas Hannas and Rinawaty Rinawaty, "Apologetika Alkitabiah Tentang Penciptaan Alam Semesta Dan Manusia Terhadap Kosmologi Fengshui Sebagai Pendekatan Dalam Pekabaran Injil," DUNAMIS: Jurnal Teologi Dan Pendidikan Kristiani 4, no. 1 (2019): 55-74. 
manusia lainnya. Sebagai makluk sosial yang memerlukan kerja sama dalam membangun peradaban. Hal itu seperti nilai dalam sila Kemanusiaan yang adil dan beradab secara substansial memiliki kekhasan yaitu terkait dengan pengakuan martabat kemanusiaan yang berdimensi religius. Artinya, bahwa martabat kemanusiaan dengan segala implementasinya haruslah bertumbu pada nilai-nilai kemanusiaan yang sesuai dengan nilai-nilai Ketuhanan. ${ }^{44}$ Pancasila sebagai dasar untuk menghargai dan bahu membahu serta sebagai kompas dalam menunjukkan hidup yang berkualitas, dengan demikian menciptakan perubahan bagi bangsa dan masyarakatnya. Dari penjelasan tersebut adanya hukum kasih menjadi dasar menjalankan ideologi dan nilai-nilai Pancasila yaitu mengasihi Tuhan berarti mengasihi sesama dengan mengejawantahkan dalam kehidupan sehari-hari. ${ }^{45}$ "Kemanusiaan yang adil dan beradab juga merupakan sikap yang teguh dalam memberikan makna bahwa setiap manusia adalah makhluk yang beradab yang perlu diakui dan diperlakukan sesuai harkat dan martabat selaku ciptaan Tuhan yang memiliki derajat, hak dan kewajiban yang sama. ${ }^{46}$

Manusia merupakan ciptaan Allah yang ditempatkan di tengah ciptaan lain sebagai pelayan, kawan sekerja dan tunduk dalam setiap pekerjaan Allah. Manusia diciptakan serupa dan segambar dengan Allah, dengan pengetahuan, kebenaran dan kekudusan. Sebagai gambar Allah manusia memiliki kehendak bebas yang memiliki kemampuan bebas untuk taat atau tidak pada hukum Allah. Manusia yang terdiri dari Roh, jiwa dan raga adalah manusia yang memiliki dimensi kekekalan atau suatu wujud yang abadi, tetapi yang diciptakan juga sebagai bagian manusia paling luhur yang dapat diekspresikan melalui perbuatan baik dan menghargai manusia. Meskipun manusia dalam rupa lahiriah mencerminkan kemuliaan Allah, tetapi gambar Allah sebenarnya terdapat dalam jiwa. Allah membuat hubungan perjanjian dengan manusia. Allah menjanjikan berkat dan rahmatNya sedangkan manusia harus menguasai alam dengan menyadari statusnya sebagai ciptaan di bawah kuasa kedaulatan Allah. ${ }^{47}$

Oleh sebab itu, manusia disebut sebagai mandataris Allah, dalam Kejadian 1:28 dikatakan bahwa manusia diberi kuasa atas alam semesta. Allah mempercayakan kepada manusia tugas dan tanggung jawab untuk memperbanyak keturuanan yang memenuhi dan menaklukan bumi, serta berkuasa atas ikan-ikan dilaut, burung-burung di udara, serta segala binatang yang merayap di bumi. Dalam proses penciptaan Hawa (Kej. 2:18), Allah menyatakan bahwa tidak baik bagi manusia untuk seorang diri saja, sehingga Ia menjadikan penolong bagi manusia, yang sepadan dengannya. Sebelum Hawa diciptakan, telah banyak ciptaan Tuhan yang lain, seperti hewan dan tumbuhan yang menemani Adam, namun semuanya tidak sepadan dengannya. Manusia merupakan mahluk sosial yang tidak dapat hidup sendiri, manusia memerlukan manusia lain dalam hidupnya. Hal inilah yang harus dijunjung tinggi untuk memerangi prinsip fundamental tentang kerukunan yang tidak menjadi prioritas bermasyarakat saat ini.

\footnotetext{
${ }^{44}$ Sutono and Purwosaputro, "Aksiologi Pancasila."

${ }^{45}$ Samarenna, "Penghayatan Dan Pengalaman Pancasila Dalam Refleksi Matius 22: 37-40."

${ }^{46}$ Samarenna.

${ }^{47}$ Jefri Wungow, "Indonesianisasi Kritologi Perikemanusiaan Dan Kristologi: Aplikatif Sila Kedua Pancasila Dalam Kekristenan,” RHEMA: Jurnal Teologi Biblika Dan Praktika 4, no. 2 (2018).
} 


\section{Aktulisasi Iman Kekristenan dalam Menjunjung Tinggi Nilai Kemanusiaan}

Sikap positif berupa membangun kesadaran akan pentingnya berbangsa dan bernegara serta membangun mutual trust, penghargaan atas keragaman, intensifikasi dialog dan kerjasama antarumat beragama, sebagai pendukung bagi terciptanya kerukunan dalam keragaman agama dan harmoni dalam perbedaan. ${ }^{48}$ Hal tersebut adalah suatu yang menjadi point dasar berbangsa dari berbagai keanekaragaman. Dan adanya eksistensi Filsafat Pancasila sangat dibutuhkan dalam dinamika pemikiran kefilsafatan yang tetap berlandaskan pada kejatidirian manusia Indonesia yang sesungguhnya. ${ }^{49}$ Serta adanya pemahaman yang benar tentang Pancasila, dapat diterapkan dengan mengurangi eksklusivisme sosial, dan menjauhkan kesenjangan sosial dan perpecahan berdasarkan suku, agama, ras dan antar golongan. ${ }^{50}$ Namun dalam kekristenan aktualisasi terhadap nilai dan harkat serta martabat manusia wajib dan mutlak untuk dilakukan sebab mengasihi Allah dan sesama yang diajarkan dalam kebenaran Alkitab menjadi dasar untuk dilakukan sebagai bagian dari iman percaya kepada Tuhan untuk menghargai, menghormati sesama manusia. Sebab hal itu juga merupakan suatu tindakan dan mengamalkan serta sebagai bentuk penghayatan akan Pancasila. ${ }^{51}$

Dalam bingkai hidup bermasyarakat dan berbangsa, maka orang Kristen pun tetap melakukan tanggung jawabnya untuk menghayati dan mengamalkan nilai-nilai dan norma Pancasila sebagai dasar hidup berbangsa. Sebagai orang Kristen, maka pengamalan Pancasila tidak lepas dari mengimplementasikan hukum kasih. ${ }^{52}$ Sebab dalam hukum kasih seberapa besar rasa peduli terhadap sesama khususnya rasa kemanusiaan adalah bukti orang tersebut menghasihi Tuhan. Besar kecilnya rasa kemanusiaan dalam diri masing-masing akan menentukan seberapa aktif atau tidaknya dalam kegiatan kemanusiaan. ${ }^{53}$ Setiap manusia harus memandang orang lain sebagai subjek bukan sebagai objek karena dengan demikian maka manusia yang satu menganggap manusia yang lain juga sama seperti dirinya. Pemahaman yang seperti itu akan memberikan rasa empati dan kepedulian terhadap sesama manusia, sehingga muncul suatu komitmen apabila belum bisa membahagiakan orang lain maka yang terlahir dalam benaknya adalah jangan menyakiti orang lain. Oleh karena itu seharusnya setiap manusia harus menjungjung tinggi kemanusiaan dan berjuang untuk menyejahterakan masyarakat. ${ }^{54}$ sebagai mana yang Tuhan inginkan dalam kehidupan orang percaya untuk menjadi berkat dan berdampak bagi seluruh manusia.

\section{KESIMPULAN}

Nilai dan norma serta semangat dalam Pancasila sejatinya adalah luhur dan universal; menekankan semangat yang menjunjung nilai kemanusiaan, kebersamaan dan persatuan, gotong royong, toleransi dan keadilan. Namun adanya tindakan yang menyalahi dari norma agama maupun hukum yang berlaku membawa persoalan yang dapat membawa pada perpecahan sesama anak bangsa. Dapat disimpulkan, bahwa untuk mereduksi superioritas

\footnotetext{
${ }^{48}$ Sumbulah, "Pluralisme Dan Kerukunan Umat Beragama Perspektif Elite Agama Di Kota Malang."

49 Sutono and Purwosaputro, "Aksiologi Pancasila."

${ }^{50}$ Samarenna, "Penghayatan Dan Pengalaman Pancasila Dalam Refleksi Matius 22: 37-40.”

${ }^{51}$ Samarenna.

52 Samarenna.

${ }^{53}$ Kristiono, "Penguatan Ideologi Pancasila Di Kalangan Mahasiswa Universitas Negeri Semarang."

${ }^{54}$ Simanjuntak and Benuf, "Relevansi Nilai Ketuhanan Dan Nilai Kemanusiaan Dalam Pemberantasan Tindak Pidana Korupsi."
} 
dan mengamalkan sila kemanusiaan yang adil dan beradab dalam persepektif Kristen, setiap anak bangsa harus dapat menghilangkan rasa superior dari segala sisi terhadap sikap menghargai sesama dengan mereduksi paradigma hakikat kemanusiaan yang salah. Sebab hal itu menjadi pegangan yang utuh untuk persatuan yang mana menjadi dasar berbangsa dan bernegara. Selanjutnya, orang percaya dapat melihat sisi kemanusiaan dalam konsep kemanusian yang adil dan beradab dalam pandangan Alkitab, sehingga hal itu dapat membawa orang percaya mampu mengaktulisasikan iman Kekristenan dalam menjunjung tinggi nilainilai kemanusiaan.

\section{REFERENSI}

Arifin, Ridwan, and Lilis Eka Lestari. "Penegakan Dan Perlindungan Hak Asasi Manusia Di Indonesia Dalam Konteks Implementasi Sila Kemanusiaan Yang Adil Dan Beradab.” Jurnal Komunikasi Hukum (JKH) 5, no. 2 (2019): 12-25. https://doi.org/10.23887/jkh.v5i2.16497.

Aristin, Rini. "Aktualisasi Sila Kemanusiaan Yang Adil Dan Beradab Di Era Reformasi." Aspirasi : Jurnal Ilmiah Administrasi Negara 1, no. 1 (2016): 27-36. http://ejournal.unira.ac.id/index.php/jurnal_aspirasi/article/view/39/24\%0Ahttp://ejo urnal.unira.ac.id/index.php/jurnal_aspirasi/article/view/39.

Asmaroini, Ambiro Puji. "Menjaga Eksistensi Pancasila Dan Penerapannya Bagi Masyarakat Di Era Globalisasi." JPK: Jurnal Pancasila Dan Kewarganegaraan 1, no. 2 (2017): 50-64.

Ayu, Felisia Mega Sri, and Anita Trisiana. "Penguatan Pancasila Dalam Perbuatan (Alternatif Tindakan Kuratif Di Era Globalisasi)." Jurnal Global Citizen: Jurnal Ilmiah Kajian Pendidikan Kewarganegaraan 4, no. 2 (2018): 14-19.

Benuf, Kornelius. "Politik Hukum Legislator Dan Ideologi Pancasila." Gema Keadilan 5, no. 1 (2018): 85-92.

Busroh, Firman Freaddy. "Upaya Pencegahan Korupsi Melalui Reaktualisasi Nilai-Nilai Pancasila." Jurnal Ilmiah Lex Publica IV, no. 1 (2017): 631-44.

Febriansyah, Ferry Irawan. "Keadilan Berdasarkan Pancasila Sebagai Dasar Filosofis Dan Ideologis Bangsa.” DiH: Jurnal Ilmu Hukum 13, no. 25 (2017): 1-27. https://doi.org/10.30996/dih.v13i25.1545.

Hannas, Hannas, and Rinawaty Rinawaty. "Apologetika Alkitabiah Tentang Penciptaan Alam Semesta Dan Manusia Terhadap Kosmologi Fengshui Sebagai Pendekatan Dalam Pekabaran Injil.” DUNAMIS: Jurnal Teologi Dan Pendidikan Kristiani 4, no. 1 (2019): 55-74.

Iswara, Aditya Jaya. "6 Bukti Netizen Indonesia Tidak Sopan Se-Asia Tenggara, Akun Luar Pun Diserang." Kompas.com, 2021. https://www.kompas.com/global/read/2021/04/14/100430270/6-bukti-netizenindonesia-tidak-sopan-se-asia-tenggara-akun-luar-pun?page=all.

Karimah, Umiarti. "Kemanusiaan Yang Adil Dan Beradab Perspektif Al-Quran (Studi Komparatif Tafsir Al-Misbah Dan Al-Huda)," 2018. http://repository.iiq.ac.id/handle/123456789/753.

Krisnamukti, Bagus Pradhana, Kadek Gita Hartini Dhamayanti, Yovita Maharani, and Shania Aliyya Putri. "Nilainilai Pancasila Menjadi Pedoman Atau Normal Bagi Masyarakat Dalam Kehidupan Sosial Yang Terdapat Kemajemukan Suku, Budaya, Ras Dan Agama Untuk Tetap Saling Menjaga Persatuan Dan Kesatuan, Menjaga Kerukunan, Serta Menghindari Sikap Etnosentrisme.” Jurnal Rontal Keilmuan Pancasila Dan Kewarganegaraan 6, no. 1 (2020): 66-72. 
Kristiono, Natal. "Penguatan Ideologi Pancasila Di Kalangan Mahasiswa Universitas Negeri Semarang." Harmony 2, no. 2 (2017): 193-204.

Lestari, Sulistyani Eka. "Kajian Islam Terhadap Sila Kedua Dalam Pancasila Sebagai Penjaga Multikulturalisme.” Pendidikan Multikultural 3, no. 2 (2019): 190-206. https://doi.org/10.33474/multikultural.v3i2.4759.

Pranarka, A.M.W. Sejarah Pemikiran Tentang Pancasila. Jakarta: Yayasan Proklamasi, 1985.

Rosana, Ellya. "Eksistensi Pancasila Sebagai Kontrak Sosial Umat Beragama.” Jurnal Tapis: Jurnal Teropong Aspirasi Politik Islam 13, no. 2 (2017): 1-17.

Samarenna, Desti. "Penghayatan Dan Pengalaman Pancasila Dalam Refleksi Matius 22: 37-40.” JURNAL TERUNA BHAKTI 3, no. 1 (2020): 36-47.

Simanjuntak, Supriardoyo, and Kornelius Benuf. "Relevansi Nilai Ketuhanan Dan Nilai Kemanusiaan Dalam Pemberantasan Tindak Pidana Korupsi." DIVERSI : Jurnal Hukum 6, no. 1 (2020): 22-46. https://doi.org/10.32503/diversi.v6i1.890.

Soejadi. Pancasila Sebagai Sumber Tertib Hukum Indonesia. Yogyakarta: Lukman Offset, 1999.

Sumbulah, Umi. "Pluralisme Dan Kerukunan Umat Beragama Perspektif Elite Agama Di Kota Malang." Analisa Journal of Social Science and Religion 22, no. 1 (2015): 113.

Sutono, Agus, and Supriyono Purwosaputro. "Aksiologi Pancasila." Jurnal Ilmiah Civis 8, no. 2 (2019): 67-86.

Umrati, and Hengki Wijaya. Analisis Data Kualitatif Teori Konsep Dalam Penelitian Pendidikan. Sulawesi Selatan: Sekolah Tinggi Theologia Jaffray, 2020.

Wibisono, Gunawan. "Membendung Paham Radikalisme Agama Dan Ekstrim Kiri Dalam Mempertahankan Eksistensi Pancasila." Communitarian 1, no. 1 (2018).

Wungow, Jefri. "Indonesianisasi Kritologi Perikemanusiaan Dan Kristologi: Aplikatif Sila Kedua Pancasila Dalam Kekristenan." RHEMA: Jurnal Teologi Biblika Dan Praktika 4, no. 2 (2018).

Yanto, Dwi. "Pengamalan Nilai-Nilai Pancasila Sebagai Pandangan Hidup Dalam Kehidupan Sehari-Hari." Ittihad 14, no. 25 (2016): 35-45. https://doi.org/10.18592/ittihad.v14i25.860.

Yunitasari, Dukha. "Mengupas Hakikat Manusia Sebagai Makhluk Pendidikan Dan Implikasinya." Pelita Bangsa Pelestari Pancasila 13, no. 1 (2018): 77-93. 